Fernando Alegría

\title{
Hacia una definición de la poesia chilena
}

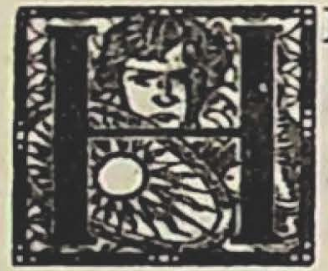

E AQUI una pregunta que debiera preocupar a nuestros críticos y poetas: ¿ha contribuido Chile, en verdad, a la literatura moderna con una expresión poética característica, sólidamente integrada en sus diversos elementos y de significación universal? Los escasos críticos chilenos que se aventuran en el mundo complejo de la poesía contemporánea tácitamente nos están indicando con sus evasiones que Chile posee un grupo más o menos numeroso de insignes poetas, pero no una poesía propia. La razón íntima de este parecer, que les lleva a asumir el hecho superficial para no comprometerse en la dilucidación de un problema que atañe a lo más hondo del esfuerzo creador, pudiera hallarse en dos actitudes que considero típicas de la crítica en Chile: por una parte, ella estudia a la poesía chilena en un vacuum, sin relacionarla con la expresión poética del mundo contemporáneo, limitándose a lo sumo a señalar antojadizas influencias o casuales similitudes temáticas; por otra parte, existe en la crítica chilena la tendencia a ver en la poesía el hecho histórico y no el estético; se estudia, por consiguiente, la biografía del poeta y no su poesía, ni mucho menos el intento teórico que trata de fundamentarla. 
De ahí que, tanto en la reseña histórica como en las valoraciones antológicas, la poesía chilena aparezca inconexa, sin tradición e indefinida, hasta el punto de que el observador inexperto llega a considerarla como un ocasional resplandor retórico y no como una unidad de pensamiento y emoción a través de un rico proceso formativo. La agresividad individualista de los poetas chilenos más famosos algo ha tenido que ver con la timidez e insuficiencia de los críticos. Celosos de su originalidad intimidan a quien se les acerca con los instrumentos usuales de la literatura comparada; defensores apasionados de su posición directora ofenden a sus colegas, llegando a establecer una atmósfera de odio que alcanza a sus discípulos y aun al público lector. ¿Quién ha estudiado en Chile con criterio objetivo y crítico el problema de las influencias recíprocas que existen en la poesía de Gabriela Mistral, Pablo de Rokha, Vicente Huidobro y Pablo Neruda? Nadie se atreve a considerarles otra cosa que fenómenos individuales en un vacío celestial donde giran en órbita propia con un modesto agregado de satélites. Supongo que el crítico que se atreviera a incursionar por los comienzos de la poesía moderna chilena, comparando, examinando, clasificando, no llegaría a publicar sus conclusiones si pensara solamente en la descarga eléctrica que le espera a manos de polemistas tan ejercitados y tan sutilmente feroces.

No obstante, ese estudio de antecedentes literarios es impostergable. En parte, muy somera, lo llevé a cabo en el curso de mi investigación sobre la influencia de Walt Whitman en la poesía hispanoamericana (1). Sobre la base de un conocimiento y de una devoción comunes logré establecer ciertos nexos en la obra de esos poetas; nexos que no son sino un fundamento para buscar concomitancias de variado carácter, temático, lingüístico, filosófico. Analizados desde este punto de vista cada uno de los poetas nombrados aporta factores importantes a la configuración de un estilo que, por ser característicamente chileno, marca nítidamente a nuestra poesía en la literatura contemporánea. Estilo cuyo período de gestación comienza en los últimos veinte años del siglo XIX -cuando el ars poetica del neoclasicismo romántico expuesta por Andrés Bello (2) 
y Eduardo de la Barra (3) entra en crisis-, se extiende a través del fugaz predominio de Darío en Chile y del período tolstoyano de Los Diez, y encuentra sus primeras definiciones hacia 1920 incorporado a tres tendencias que han de mantener su validez hasta el día de hoy: el realismo alegórico-sentimental de Gabriela Mistral, el abstraccionismo de Vicente Huidobro y el surrealismo regionalista de Pablo de Rokha. Lo que se llama romanticismo de tono menor en Guillermo Blest Gana y en Soffia, lo que se considera modernismo en Pedro Antonio González, en Magallanes Moure y en Pezoa Véliz, criollismo en Diego Dublé Urrutia, "arte revolucionario" en A. Bórquez Solar y Víctor D. Silva, y simbolismo en Pedro Prado, son también elementos básicos que van a integrar más tarde el gran estilo barroco chileno, cuya expresión máxima la alcanzará Pablo Neruda acercándose al medio siglo.

No es mi propósito, por ahora, adelantar una definición de la poesía chilena contemporánea sino examinar uno de los más recientes estudios que se han hecho sobre este asunto y determinar hasta qué punto contribuye a formular tal definición. Me refiero al prólogo que Jorge Elliott ha escrito para su Antología crítica de la nueva poesía chilena (4). Cronológicamente, Elliott limita sus observaciones al período que se extiende desde 1910, más o menos, hasta el presente. Su propósito fundamental es ofrecer una selección poética que ilustre el desarrollo de ciertas tendencias estéticas a través de escuelas o grupos ya consagrados por la crítica oficial.

Consciente, al parecer, del vacuum en que flota la poesía chilena contemporánea, Elliott se apresura a fijarse un punto de referencia en la literatura europea: escoge la poesía inglesa; aunque se apoya también, pero de modo más esporádico, en la poesía norteamericana. Pronto advierte el lector que este punto de referencia es exiguo para abarcar el fenómeno literario a que se orienta. Elliott intenta explicar no sólo las constantes estéticas de la poesía chilena, sino también la teoría general del nuevo arte poético y su base filosófica, recurriendo exclusivamente a una exposición del romanticismo inglés. Su aparato ideológico resulta, entonces, desconcertante, pues para enfrentarse 
a los problemas de la cultura en el mundo moderno se arma de ideas y teorías cuya beligerancia histórica corresponde al auge de las doctrinas positivistas.

"No es posible - afirma Elliott- referirse a la poesía chilena en particular sin antes aludir, aunque sea en forma esquemática, al problema general de la poesía. Este problema es, en realidad, el problema de todo el arte, y podríamos resumirlo en la palabra potencialización. Un poema, un cuadro, una escultura o un trozo de música, deben poseer una potencia especial que los capacite para penetrar más allá de la superficie sensorial y operar dentro del hombre, en la fuente misma de su vida emocional... Desgraciadamente el avance de la civilización ha creado tanta actividad de orden racional, que el hombre encuentra una dificultad creciente para expresar sus vivencias emotivas con potencialidad. El racionalismo ha engendrado una teoría del conocimiento que, a su vez, ha impuesto un concepto nuevo de la realidad en relación a la sustentada en etapas anteriores de la cultura. Esta ve como real ante todo lo objetivo y comprobable, cuyo comportamiento ha estudiado hasta verlo sometido a leyes mecánicas. Estas leyes se han observado empíricamente en cierto número de fenómenos y por un acto de fe, bastante inexplicable, se ha llegado a considerar universales. En tales circunstancias las aprehensiones intuitivas y los procesos imaginativos no se valoran debidamente y por lo tanto el arte sufre" ( $O p$. cit., págs 24-25).

¿En qué época escribe Elliott? ¿Con qué fantasmas del siglo XIX dialoga, en qué limbo sitúa a sus hombres de ciencia, a sus filósofos y poetas? Una opinión como ésta expresada antes de que Bergson definiera su filosofía del conocimiento intuitivo y que la estética ahondara, como consecuencia, en el concepto valorativo de la imagen, antes de que Freud, sus discípulos y continuadores, abriesen un campo virgen a la literatura con sus teorías sobre el subconsciente, no sorprendería. Pero hoy... ¿Que no se valoran debidamente los procesos imaginativos? ¿Y la física moderna, para no citar sino un ejemplo, qué es sino una espléndida aventura en el mundo de las abstracción, en los ámbitos más remotos de la imaginación y la 
fantasía? El mismo Elliott debe contradecirse unas páginas más adelante afirmando:

"La ciencia es, como decíamos, responsable hasta cierto punto por el estado actual del arte... Solamente en los últimos años ella ha podido penetrar tan hondo en la materia que su visión de ella ha atravesado los límites sensoriales para entrar en el terreno de lo metafísico" (página 26).

Analizando el "problema de la poesía" sobre la base de una exposición elemental de la poética del romanticismo inglés, poco o nada dice el autor de los grandes planteamientos teóricos que constituyen los pilares de la poesía chilena contemporánea. Apenas se alude a los temas que el crítico debió discutir si había de enfrentarse al creacionismo de Vicente Huidobro, al surrealismo de Pablo de Rokha, al trascendentalismo de Pablo Neruda y al neosimbolismo de las nuevas generaciones.

Frente al desarrollo mismo de la poesía chilena Elliott procede con marcada reticencia. Sus ligerísimas notas acerca de los orígenes de la poesía chilena están basadas en observaciones de Bello, Medina y Galdames. Ciertas frases sobre la antología de Menéndez y Pelayo, así como una nota al final del capítulo II, indican que el autor conoce nuestra interpretación de La Araucana (5). Prefiere, sin embargo, repetir lugares comunes de la crítica del siglo XIX a considerar las innovaciones de la crítica moderna. A pesar de que su objetivo es la poesía de los primeros cincuenta años del presente siglo, se aventura en el campo de la poesía de transición, escrita a fines del siglo XIX y a principios del XX. Sus apreciaciones a este respecto son muy generales:

"Los iniciadores de la poética de este siglo fueron todos poetas menores; su obra es pobre de contenido emocional y su vivencia poco profunda, residiendo su virtud mayor en la sensibilidad con que expresan estados de ánimo nostálgicos, ocurrencias de un ingenio agradable pero nunca penetrante. También en su verdadero amor por el oficio, su gracia en el manejo de la palabra y en la vitalidad visual de mucha de su metáfora. Los mejores poetas de esta etapa 
expresan, además, un algo subjetivo, íntimo y delicado. Pezoa Véliz, Magallanes Moure, Mondaca, González Bastías y otros han escrito poemas dignos de la más exigente antología. En general, diríamos que los hechos sucedían como era debido ya que no nacen grandes poetas en forma espontánea..." (página 43).

La peculiaridad de esta prosa no logra disminuir el conformismo rutinario de los juicios que el autor sustenta. Asimismo, cuando Elliott observa la "pobreza" de esos años de sentimentalismo modernista y, aduciendo razones históricas y sociales, contrasta la falta de raíces criollas en la poesía culta y el acendrado regionalismo de la poesía popular, sus conclusiones pecan, en el fondo, de extremada simplificación.

"La poesía popular - dice- revela en cuán alto grado la actitud asumida por los poetas cultos distaba del temperamento nacional y de las vivencias genuinas del pueblo" (página 44).

$Y$ añade:

"No hay, entonces, en esa poesía menor (se refiere a la "culta"), a pesar de su sensibilidad y delicadeza, aquella reverberación de la vida en lo íntimo del ser viviente que da fuerza a todo arte de verdad poderoso. Es esto lo que va a estar presente en lo mejor de la nueva poesía” (página 48).

Observaciones son éstas que nadie podría refutar si los hechos literarios fueran de una sencillez y una precisión aritmética. Dividida la poesía chilena de comienzos del siglo XX en dos mitades, una culta y una popular, una artística y otra folklórica, una sentimental y otra social, los poetas caerían pesadamente en sacos que el crítico, como el agricultor, podría almacenar en separadas bodegas. Pero la poesía no es una naranja que pueda partirse en dos hemisferios dorados. ¿Dónde está en el ensayo de Elliott la explicación del tono vehementemente social, realista, satírico, tribunicio $\mathrm{y}$, en sus últimos extremos, dramáticamente prosaico, de los poetas que él descarta como "artísticos", "cultos", evadidos de la realidad nacional: Bórquez Solar, Víctor D. Silva, Dublé Urrutia y Pezoa Véliz? ¿Dónde la 
interpretación de ese patético desconcierto que lleva a esos poetas a contradecir cada verdad social con un epíteto retórico y cada metáfora decadentista con un exabrupto de indignada protesta patriótica? ¿Dónde se considera el drama poético de Pezoa Véliz, colaborador anónimo y frustrado del Ciego Peralta, discípulo tímido y candoroso de la decadencia sofisticada de Gutiérrez Nájera y Amado Nervo?

En esos primeros quince años de nuestro siglo los poetas chilenos viven un proceso de crisis ideológica y social que corresponde a la marea política de la revolución industrial que se avecina. Elliott no parece interesarse en el complejo diseño de esta época de colonias tolstoyanas y anarquismos mutualistas. El país no alcanza aún el climax de la euforia salitrera, pero sí derrocha sus riquezas en una fantástica parodia de la decadencia francesa. Tampoco le atraen a Elliott las expresiones de esa misma crisis en el campo del ensayo (Francisco Encina, Armando Donoso), del cuento (Baldomero Lillo, Rafael Maluenda), o de la novela (Augusto d'Halmar, Fernando Santiván), todas ellas de indiscutible utilidad para explicar el fenómeno poético. Simplificada la historia de la literatura chilena, Elliott se fija hitos innecesarios:

"Es difícil establecer con quién se debería comenzar un estudio de la nucva poesía. Lo exacto es que nace con Huidobro, Neruda y de Rohka, pero no se puede tampoco ignorar a Gabriela Mistral.. Pero si miramos en este sentido a Gabriela Mistral, no podemos desconocer a Pedro Prado... En tal caso tampoco se puede desconocer la obra de Pezoa Véliz..." (páginas 48-49).

Juzga, entonces, la obra de los precursores. De Pezoa Véliz dice: "Hoy día se lee a Pezoa Véliz con interés y agrado debido a que nos conmueve su absoluta falta de pretensión y la pretensión es uno de los mayores defectos de mucha de la nueva poesía. Pero esto no bastaría; luego se le descubre, además, un instinto expresivo considerable y se ve que su dicción poética, a pesar de estar presa en el convencionalismo verbal romántico... y cargada de recursos daríescos... logra un acercamiento notable al idioma cotidiano y se 
amarra a incidentes locales que ubican la experiencia sin que el regionalismo sea forzado o le impida llegar a un algo muy fino en su sensibilidad" (página 50).

Este mismo tono altamente impresionista envuelve sus opiniones acerca de Pedro Prado, de quien dice que contribuye a la poesía nueva por el uso del verso libre y porque combina el simbolismo y el naturalismo. Le censura su falta de "presión vivencial" y anota que, en su última época, abandonó la "oblicuidad" y adoptó la forma clásica para tratar "temas de angustia existencial eternos y a través de símbolos tradicionales” (páginas 51-52).

A la obra de Gabriela Mistral se acerca Elliott con observaciones perspicaces y certeras. Señala, por ejemplo, el efecto saludable de su ruralismo en un momento en que la fiebre modernista conducía a los poetas menores a confundir el estilo con la simple ornamentación. Gabriela Mistral impone und decorosa sobriedad en el lenguaje para aumentar así la carga emotiva con la esencia del sentimiento, sin recurrir a trucos literarios de simple afectación. Elliott destaca muy hábilmente el fondo chileno de la poesía crótica de Gabriela Mistral, su "elemental" condición campesina en que se mezcla la fuerza pasional, el supersticioso afán de posesión mágica, la veleidad, el dolor, la ternura arrebatada de un temperamento primitivo.

"Sucede - dice Elliott- que la poesía de Gabriela Mistral aún antes de que aludiera a los grandes ritos de la antigüedad era una poesía ritual; la religiosidad de nuestra poetisa la induce a hacer de sus poemas "rezos" o "encantamientos" (página 57).

En Lagar el espiritualismo de esta poesía adquiere un profundo sentido vital, un dinamismo en el que viene a sintetizar Gabriela Mistral la expresión última de su concepción del mundo. En cada situación poética "algo entra al mundo, y, al hacerlo, entra también en nuestras vidas, de modo que el existir es estar incorporado a cosmos que pululan, cuya complejidad se incrementa de momento a momento, presionando sobre nuestras vidas; de mundo a ser hay un místico y constante flujo... Su poesía - concluye Elliott- es religión, es rezo, en cuanto alumbra, canta, celebra y finalmente conduce a 
una "mimesis" general del hombre con todo lo creado" (páginas 57-58).

Si alguna crítica pudiera hacerse a la interpretación de Elliott es que no capta el desarrollo armónico de la religiosidad de Gabriela Mistral a través de toda su obra. Sus primeros poemas no son aspectos aislados de una crisis amorosa que busca el consuelo de la religión. Son, en cambio, el aprendizaje, medido en profundidad y en intensidad, de una sublimación en que los incidentes eróticos se transfiguran e incorporan a los símbolos fundamentales del dogma católico, símbolos que en Tala alcanzan su pleno poder intrigándonos desde su reino de luces y sombras. Elliott no discute el aspecto doctrinario de la poesía de Gabriela Mistral, sino que pone de relieve únicamente lo que esa poesía encierra de ejercicio lírico en medio de fuerzas telúricas y pasionales.

Si la obra de Gabriela Mistral aparece iluminada en este ensayo por medio de novedosas sugerencias, la de Vicente Huidobro, por el contrario, se sumerge en brumas imprecisas. Elliott le dedica diez páginas, pero de esas diez páginas siete constituyen un resumen de las lecturas del antologista acerca de la "poesía pura” en Inglaterra, en otra se reproduce una larga cita de Dylan Thomas y las dos restantes se componen de una adjetivación más o menos elogiosa. No se discute aquí el problema de las fuentes literarias y filosóficas de los famosos Manifestes de Huidobro. No se plantea la necesidad que existe de revalorizar la aportación de Huidobro a la poesía y al ambiente literario chilenos ahora que el fetichismo característico de sus espectaculares campañas ha perdido toda virulencia. Elliott se contenta con adjetivar:

"Altazor - declara- es un libro importante, experimental en la forma y con un impulso romántico de gran carga subjetiva. Por ello afecta poderosamente a la naciente poesía nueva y le imprime un tono de amplitud cósmica que luego impera en ella largo tiempo, fuera de que introduce un vocabulario que ha dejado rastros permanentes en la dicción poética hasta la actualidad" (página 71).

En el párrafo anterior subrayo ciertos adjetivos y adverbios que 
indican el carácter "impresionista" de la crítica de Elliott en sus momentos más débiles.

Me parece justo dirigir también la atención del lector a un curioso caso de coincidencia a la distancia - que se le escapa a Elliotty que atañe a la cita de Dylan Thomas en las páginas 77 y 78 . Compárense las palabras de Thomas con otras del escritor argentino Jorge Luis Borges que cito a continuación.

"Un poema mío - dice Thomas- requiere de :una multitud de imágenes, porque su centro o núcleo es una multitud de imágenes. Creo una imagen o más bien dejo que una imagen se cree a sí misma por medio de la emoción y luego le aplico toda mi capacidad crítica e intelectual para que ella engendre otra... Cada imagen mía lleva en sí la semilla de su destrucción y mi método dialéctico, tal cual lo entiendo, da un constante surgir y morir de imágenes a partir de una semilla central... del inevitable conflicto de imágenes -inevitable por la naturaleza creadora, recreadora, destructora y contradictoria del motivo central, vientre de la conflagración- intento lograr una paz que es el poema” (páginas 77-78).

El ultraísmo dice Borges, por su parte, "es la reducción de lo lírico a su elemento primordial, la imagen. Eliminando las frases intermedias, inútiles adjetivos de conexión... los poemas ultraístas consisten, entonces, de una serie de imágenes, cada una de las cuales contiene su propia cualidad sugestiva y resume una intocada visión de algún fragmento de la vida" (6).

Sabida es la influencia poderosa que ejerció Huidobro en los comienzos del ultraísmo español. Puede uno imaginar que Borges no fue ajeno a ese interés profundo que poetas como Juan Larrea y Gerardo Diego sinticron por las teorías creacionistas del poeta chileno. Lógico habría sido, entonces, que el autor estudiara en un aparte este problema de fuentes y doctrinas, de coincidencias y aproximaciones, que toca en zona importante a la poesía chilena.

Pablo de Rokha es uno de los poetas que interpreta Elliott con un mínimum de lucubración. De su poesía de los últimos años dice: "Sin embargo, a medida que la poesía de de Rokha adopta un 
mensaje se hace más externa, pierde su grave lirismo, que le podría haber permitido captar el aspecto místico de Whitman, se pone excesivamente retórica e intenta mantener su carga emocional a través de una adjetivación enfática que habla de una emoción que no encontramos en la substancia de los poemas. Todo se vuelve "sangriento", "colosal", "gigante" o "tremendo", sin que veamos, finalmente, que así lo sea. Por esto esa adjetivación termina por conceder sólo un tono de imprecación” (página 83).

Reconoce, no obstante, que en sus "poemas y prosas populares" alcanza una "robustez y un vigor elemental innegable" y le adscribe a su obra entera una función directora en la época inicial del ruralismo, junto a la poesía de Gabriela Mistral. Las reservas de Elliott con respecto al lenguaje rokhiano se explican si se considera que, por lo general, Elliott busca en la poesía una elaboración artística premeditada e intensa, mientras que de Rokha se entrega en cuerpo y alma a una libre floración del idioma popular chileno, al que levanta de su condición de slang callejero confiriéndole un genuino poder literario. Elliott considera la poesía de Pablo de Rokha en su aspecto más obvio de sentimentalidad neorromántica, no la sigue en sus retorcimientos barrocos ni en su militancia surrealista.

De mayores consecuencias me parece ser la incursión de Elliott por el vasto mundo poético de Pablo Neruda, no exactamente por la originalidad de sus juicios, en ocasiones llega a ser irritante su falta de referencias críticas que impongan al lector de las fuentes que usa (7), sino por la presteza con que responde a las insinuaciones, evocaciones y sugerencias del poeta, actuando a veces con la fascinante plasticidad de un medium. Los nombres de los intérpretes más famosos de Neruda están presentes mirándonos de soslayo, ayudando al crítico en su improvisación, ofreciéndole la materia prima que transmutará con variada fortuna. Este júbilo crítico impide, por ejemplo, determinar exactamente cuánto le debe Elliott a Amado Alonso (páginas 90-92) y a George S. Frazer en su discusión de la técnica poética de Neruda. En todo caso, en su forma metafórica ese material crítico le pertenece. La siguiente “impresión" puede conside- 
rarse típica del fenómeno a que aludimos. Refiriéndose a la enumeración caótica de Neruda (en ninguna parte dice Elliott que se debe a Leo Spitzer la acuñación de esa categoría crítica tan aplicada ahc. ra a la técnica del poeta chileno) expresa:

"Logra su propósito de tal modo, que al leer sus poemas tenemos la sensación de estar con el poeta en el momento en que se apodera de él un estado de ánimo que lo exalta y sobre el cual nos está informando minuto a minuto. Resulta algo tan excitante como la narración de un speaker que presencia inesperadamente un accidente aeronáutico, un terrible incendio o, mejor aún, que ha bajado de buzo a las profundidades del océano y que describe asombrado, por un micrófono colocado en su escafandra, ese universo obscuro y aterrador" (página 92).

Con otras palabras más recargadas de aparato erudito y más restringidas por su pudor académico, Amado Alonso ha dicho lo mismo. Pero Elliott, tocado en lo más íntimo por la magia del poeta, funciona con él y se atreve a poetizar lo que otro crítico hubiese dicho en prosa en una nota bibliográfica. Que tal procedimiento encierra un arma de dos filos, no es necesario decirlo; el mismo Elliott se encarga de probarlo unas páginas más adelante tratando de parafrasear a Humberto Díaz Casanueva.

Sorprende al lector que Elliott no se ocupe con detenimiento ni del Canto General ni de las Odas elementales. Creo que, al menos, debió fundamentar su desdén por estas obras, así como abunda en razones para justificar sus elogios a Residencia en la Tierra. Del Canto General hay una somerísima evaluación que sirve, por lo demás, como base para resumir la opinión del crítico sobre la obra reciente de Neruda:

"En Canto General existe un número sorprendente de poemas de gran calidad y debemos confesar que el libro posee una consistencia superior a la que esperábamos, pero es una obra voluminosa y tiene sus caídas también. Nos parece que Neruda levantó una dicción poética especial cuando se hallaba sometido a ciertas presiones psíquicas definidas y ese lenguaje no opera con igual eficacia fuera 
de ellas. Su nueva poesía confirma, claro, su brillante barroquismo, su poder metafórico y su riqueza imaginativa, pero le falta centripetación" (página 95).

"Centripetación" debe ser algo sumamente grave, pero no mortal, ya que el mismo Elliott se encarga de disipar los temores que pudo haber despertado con esa palabra:

"No obstante, nuestra desilusión es relativa ya que si él no hubiese escrito Residencia en la Tierra siempre habría sido uno de los grandes poetas de América. Su poesía posterior, aunque de menor potencia, posee, es claro, una altura" (página 95).

Lo que sigur: en este ensayo en relación con la poesía chilena escrita en los últimos veinte años es fascinante por sus atisbos, sus sugerencias, sus omisiones y su desorden. De los llamados "cuatro grandes" đe la poesía chilena Elliott pasa sin transición a dos poetas que deja, luego, flotando entre frases inconsecuentes: Omar Cáceres y Julio Barrenechea. Del primero nos dice que es un poeta "al cual se ha llamado maldito" y del segundo que es autor de una "poesía de tono menor" en la que hay "hallazgos expresivos tanto en la metáfora como en el tono..." Nada más. Por muy discutibles que sean los méritos de estos poetas - itan dispares!- creo que Elliott debió justificar el lugar que les asigna en esta Antología con argumentos de mayor envergadura. La poesía de Cáceres es, en mi opinión, un nexo valioso en el desarrollo del neosimbolismo chileno, junto a la de Gustavo Ossorio y a la de Gonzalo Rojas. Barrenechea, por otra parte, es el heredero del sentimentalismo de principios de siglo; en su poesía sigue alentando el romanticismo provinciano de Magallanes Moure, de Daniel de la Vega, y junto a él se reúne una sencilla agregación de poetas universitarics, poetas de intrascente pero juvenil sensualismo, que constituye el coro menor de los 20 poemas de amor y una canción desesperada.

Bruscamente, Elliott aventura la siguiente afirmación:

"En el grupo urbano, es decir en el de Huidobro, nace el surrealismo en Chile y él adopta el nombre de movimiento Mandrágora" (página 96). 
Pudiera discutirse que el surrealismo nace en "el grupo urbano" y afirmarse, por el contrario, que tiene su origen en el ruralismo de Pablo de Rokha. Se busca la evidencia en el ensayo de Elliott; inútilmente, pues prosigue sin analizar la obra de Braulio Arenas, el jefe de la Mandrágora, ni la de los poetas que le acompañan en su empresa. Se detiene en la obra de Eduardo Anguita a quien insiste en calificar como un poeta fundamentalmente católico prescindiendo, por otra parte, de un estudio de aquellos símbolos que dieran dimensión a ese calificativo. Se basa, más bien, en una declaración de principios de Anguita que debiera analizarse a la luz de las doctrinas estéticas de Menéndez y Pelayo.

Rosamel del Valle y Juvencio Valle son tan superficialmente aludidos en este ensayo - trece líneas y quince líneas respectivamenteque pueden considerarse como ausentes. Humberto Díaz Casanueva, en cambio, es objeto de un examen minucioso y surge como figura principal de un movimiento indefinido, que el lector sólo presiente a través de brumosas especulaciones. Elliott parafrasea el primer poema de La hija vertiginosa (páginas 107-109). Me atrevería a decir que la paráfrasis de Elliott constituye un poema en prosa de dudoso gusto acerca de un poema que no ha llegado a comprender del todo. Concluye censurando a Díaz Casanueva por su obscuridad, no sin que antes le compare con los románticos ingleses y alemanes y afirme que el poeta chileno, a causa de su agnosticismo, sucumbe en una penosa y pesimista concepción del ser (página 102). Intocado queda uno de los temas centrales de la poesía -de Díaz Casanueva: su alucinante y nunca resuelto conectarse con un mundo de enemigas influencias a través de seres, objetos y lugares que lo amparan en encendida atmósfera de pasiones.

El lector notará que es en estas páginas donde Elliott alcanzó el punto crítico de la poesía chilena contemporánea y pasó junto a él sin tocarlo, acaso sin advertirlo. En la poesía de Juvencio Valle, Rosamel del Valle, Díaz Casanueva, Braulio Arenas, Eduardo Anguita, Gonzalo Rojas, Venancio Lisboa, el estilo barroco chileno, que ha dado el sello a una gran época de nuestra poesía, entrega su último 
resplandor. Se encara a sí mismo, rompe el espejo que le devuelve su ajada imagen y pasa, entre espléndidas nebulosas, a probarse la retórica que será a la postre su mortaja.

Un grupo impetuoso de poetas jóvenes entrará probando armas contra la retórica obscurizante, contra la falsa golilla de la imagen sintética, contra el ensayo filosófico en verso libre, contra la crónica periodística rimada. Buscarán una nueva esencia poética en las raíces folkloricas, en la síntesis meridiana de una concepción espiritualista de la vida, a menudo católica, buscando afanosamente el milagro de la forma en los mecanismos eternos del verso. Entre estos renovadores Elliott se mueve con plausible naturalidad y acierto: la poesía de Nicanor Parra, por su estructura sencilla, su intención inmediata, su genio popular y jubilosa prestancia, despierta en Elliott ocurrencias y audacias que no se hallan en otros aspectos de su estudio. Asimismo, poetas como Gonzalo Rojas, Aldo Torres, Miguel Arteche, Venancio Lisboa, Luis Oyarzún, Enrique Lihn, Alberto Rubio, Armando Uribe, Raúl Rivera, Jorge Teiller, Hernán Valdés y otros le inspiran breves y correctas apreciaciones. Las poetisas jóvenes, en cambio, le dejan mudo. Destaca — con justicia a mi parecer- a Raquel Señoret y Raquel Jodorowsky.

Los reparos que se han hecho a la Antología de Elliott no debieran desmerecer su contribución al estudio de la poesía chilena contemporánea. Esa contribución puede resumirse diciendo que Elliott ayuda a comprender nuestra poesía con elementos de juicio que hasta hoy no había usado la crítica: me refiero especialmente a sus alusiones a la poesía de Inglaterra, a su plausible intento de relacionar el fenómeno literario con acontecimientos sociales de indiscutible trascendencia cultural, $y$, por último, a su voluntad y empeño de analizar la poesía en un plano que supera la simple reseña partidarista. Se admira, además, su sentido de selección estricta - sin caer en la pedantería-, su material bibliográfico, que, aunque incompleto, es siempre novedoso, su genuina modestia al manejar temas e ideas que, por lo común, acaban quemándoles las manos a los profesionales de la crítica. No creo que llega a definir la poesía chilena del siglo XX. 
Se acerca a ella, quiere palparla pero se le escurre como agua entre los dedos. Lucha infructuosamente por conseguir sistema y claridad en un torbellino de notas que requerían una varilla mágica para ordenarse. Su mayor mérito es, quizás, el haberse acercado a la poesía escrita en los últimos quince o veinte años para darle categoría aparte indicando que, a medio siglo, se cierra por fin el reinado de los "monstruos de la naturaleza" y queda una página en blanco en espera de otra - itodavía otra!- nueva poesía.

\section{NOTAS}

(1) Cf. Walt Whitman en Hispanoamérica, México, 1954, cap. V., página 282 y siguientes.

(2) Me refiero al discurso pronunciado por Andrés Bello en la inauguración de la Universidad de Chile.

(3) Eduardo de la Barra expresa sus ideas en La poesía, primera lección a mis alumnos de literatura, "Revista Chilena", tomo VI, Santiago, 1876, páginas $570-590$.

(4) Publicaciones del Consejo de Investigaciones Científicas de la Universidad de Concepción. Santiago, 1957.

(5) Cf. La poesía chilena, orígenes y desarrollo, etc.; México, 1954, páginas $32-42$.

(6) Tomo la cita de Borges de la Antología Twelve Spanish American Poets, prólogo y selección de H. R. Hays, Yale University Press, 1943, páginas 12-13.

(7) Como Elliott no indica sus fuentes de información es preciso culparle por ciertos errores de hecho. Por ejemplo, refiriéndose a Whitman dice:

"Además, desde ese país (Uruguay) nos llegó Walt Whitman cuya obra fue traducida al castellano en Montevideo", página 86.

Whitman no nos llegó desde el Uruguay, su introducción a la literatura hispana se debió a la famosa carta de José Martí, escrita en Nueva York, en 1887, sobre una lectura pública de Whitman. Esa carta inspiró el "medallón" a Whitman que Rubén Darío incluyó en la segunda edición de Azul... Que Leaves of Grass fuese traducido al castellano en Montevideo, según afirma Elliott, es muy discutible. La famosa traducción de Vasseur, como lo demostré en mi obra ya citada, no es una traducción directa del inglés, sino una traducción del italiano. Por lo demás, apareció en Barcelona en 1912. 